\title{
Natura i ludzie. O ekologicznej wyobraźni Tadeusza Śliwiaka
}

\author{
Katarzyna Niesporek
}

\author{
ORCID: 0000-0001-7103-9285
}

\begin{abstract}
„[...] żyjemy w czasach niechętnych drzewu. Lasy znikają, giną stare osobniki i nie wyjaśni tego sama ekonomia. Tu ona tylko współdziała, wykonuje, albowiem żyjemy jednocześnie w epoce niesłychanego marnotrawstwa. Odpowiada to jej dwóm wielkim tendencjom: niwelacji i przyspieszenia. Wysokie musi upaść, a wiek traci moc"1.
\end{abstract}

\section{Pragnienie natury}

Tadeusz Śliwiak, poeta zaliczany do pokolenia '56, w swoich utworach przyjmuje nieantropocentryczny punkt widzenia. Stając po stronie natury, dostrzega przede wszystkim zniszczenia wyrządzone jej przez człowieka. „Za swoje uznał Horacjańskie hasło naturam sequi, iść za naturalnym porządkiem. Jego poezja to próba opisu zasadniczych doświadczeń, jakie czyni człowiek, gdy wchodzi w aktywny kontakt z przyrodą, gdy ją przekształca” - pisał Artur Sandauer², „dwie z grubsza biorąc, sfery tej poezji to piękny świat natury i znamię rany, kalectwa, śmierci” - wspominał Piotr Kuncewicz ${ }^{3}$, „Śliwiak opisuje [...] świat w taki sposób, by maksymalnie ukazać służebność przyrody w stosunku do człowieka. Wszędzie dostrzega ślady więzi człowieka i natury"

\footnotetext{
${ }^{1}$ Ernst Jünger, „Drzewo”, w Wybór esejów o słowach i drzewach, wybrał i przeł. Bogdan Baran (Warszawa: Wydawnictwo Aletheia, 2017), 155-156.

${ }^{2}$ Artur Sandauer, „Poezja tragicznego ładu (Rzecz o Tadeuszu Śliwiaku)”, w Zebrane pisma krytyczne. Studia o literaturze wspótczesnej (Warszawa: Państwowy Instytut Wydawniczy, 1981), 483.

${ }^{3}$ Piotr Kuncewicz, „Tadeusz Śliwiak”, w Agonia i nadzieja, t. 3: Poezja polska od 1956 (Warszawa: Graf-PunktPolska Oficyna Wydawnicza „BGW”, 1994), 241.
} 
- uważał Konstanty Pieńkosz ${ }^{4}$, „Nie można pominąć prekursorstwa poety w zakresie wyobraźni ekologicznej" - konstatował Andrzej Juchniewicz ${ }^{5}$. Wrażliwość poety na przywołaną przez krytyków naturę ma związek $\mathrm{z}$ jego doświadczeniami wyniesionymi z dzieciństwa, związanymi z mieszkaniem wraz z rodziną na terenie miejskiej rzeźni we Lwowie. Wówczas przyroda była postrzegana przez niego jako upragnione i nienaruszone miejsce harmonii i ładu, znajdujące się poza ingerencją człowieka i zasięgiem czynionego przez niego zła, o które młody twórca codziennie ocierał się w ubojni, będąc pośrednim świadkiem niehumanitarnego traktowania zwierząt i pracujących w niej Żydów ${ }^{6}$. „[...] aby powracać do natury, trzeba najpierw istnieć jako podmiot od niej oddzielony" - pisała Julia Fiedorczuk ${ }^{7}$. Autor Widnokresu, wychowując się w rzeźni, podczas drugiej wojny światowej, temu odseparowaniu znacząco został poddany ${ }^{8}$. Pragnąc zielonej przestrzeni, zanurzał się w niej przede wszystkim w wyobraźni. W wierszu Rondo - opublikowanym w kluczowym dla tej twórczości tomiku Poemat o miejskiej rzeźni (1965) - Śliwiak, myśląc o własnym dzieciństwie, oglądając siebie w pamięci, „z zewnątrz”, wspominał:

Biegłem z rzeźni do lasu obmyć oczy ręce

z widoku i materii ciepłej krwi zwierzęcej

A ten krzyk co był we mnie teraz stał się głosem

ocierał się o korę wyprężonych sosen

Ostry krzew mnie otoczył Mech przygarnął miękki

Drzewa stały dostojnie Krwawiły ich sęki

Uciszyło się niebo zielone lesiste

Patrzyłem w moje dłonie Były znowu czyste

Jakby ptak z nich uleciał i wolnym uczynił

mnie i siebie I śpiewał I za nic nie winił ${ }^{10}$

\footnotetext{
${ }^{4}$ Konstanty Pieńkosz, Świat nadziei paradoksalnej, w Tadeusz Śliwiak, Koń maści muzycznej, wstęp i wybór Konstanty Pieńkosz (Kraków: Wydawnictwo Literackie, 1986), 12.

${ }^{5}$ Andrzej Juchniewicz, „Z czyśćca na Parnas”, Śląsk, nr 5 (2020): 63.

${ }^{6} \mathrm{O}$ mieszkaniu młodego poety na terenie miejskiej rzeźni i obserwowaniu przez niego zabijania zwierząt i Żydów, których doświadczenie Zagłady zrównuje, czyniąc zwierzęta równoprawnymi ofiarami wojny zob. Katarzyna Niesporek, „Zwierzęta i ludzie. O Poemacie o miejskiej rzeźni Tadeusza Śliwiaka”, Porównania, nr 2 (2021) [w druku] oraz Piotr Sobolczyk, „Ty jesteś krowa a ja Żyd. Tadeusza Śliwiaka Holocaust zwierząt”, Pogranicza, nr 5 (2009): 28-40.

7 Julia Fiedorczuk, Cyborg w ogrodzie. Wprowadzenie do ekokrytyki (Gdańsk: Wydawnictwo Naukowe Katedra, 2015), 66.

${ }^{8}$ Tadeusz Śliwiak we wstępie do Poezji wybranych z 1975 roku opowiadał o swoim kontakcie z naturą następująco: „Z okna naszego mieszkania oglądałem ogromny budynek chłodni i hale, gdzie zabijano zwierzęta. Po drugiej stronie ulicy znajdowała się garbarnia. Niedaleko domu rosły stare kasztany. Było ich dużo. Lubiliśmy je, my, tamtejsi chłopcy. Były długo zielone. Jak długie wakacje, jakich prawdziwie zaznaliśmy dopiero po wojnie"; „Dzisiaj jednym z najbardziej ulubionych miejsc, jakie odwiedzam najchętniej, jest bogaty w roślinny żywioł obszar Bieszczadów. Tak bardzo kontrastujący z kamienną przestrzenią tamtego miasta [Lwowa - K.N.]". Tadeusz Śliwiak, „Wstęp”, w Poezje wybrane, wyboru dokonał i wstępem opatrzył autor (Warszawa: Ludowa Spółdzielnia Wydawnicza, 1975), 10.

${ }^{9}$ Por. Jill Bennett, „Wnętrza, zewnętrza: trauma, afekt i sztuka”, tłum. Anna Kowalcze-Pawlik, Tomasz Bilczewski, w Pamięć i afekty, red. Zofia Budrewicz, Roma Sendyka i Ryszard Nycz (Warszawa: Instytut Badań Literackich PAN, 2014), 145.

${ }^{10}$ Tadeusz Śliwiak, „Rondo”, w Poemat o miejskiej rzeźni (Kraków: Wydawnictwo Literackie, 1965), 23.
} 
Miejscem schronienia bohatera lirycznego staje się natura. Już sama jego ucieczka do zielonej przestrzeni świadczy o przekroczeniu w rzeźni granic moralnych, których poeta nie może zaakceptować. W lesie szuka on zrozumienia i oczyszczenia z „widoku i materii ciepłej krwi zwierzęcej”. Śliwiak odwraca w wierszu dawniej obowiązujący biblijny rytuał ofiarny. W Liście do Hebrajczyków czytamy: „krew kozłów i cielców oraz popiół z krowy, którymi skrapia się zanieczyszczonych, sprawiają oczyszczenie ciała” (Hbr 9,13). Ma ono na celu przywrócenie równowagi, „powrót do normalnego życia osoby lub rzeczy nieczystej"11. W utworze autora Widnokresu zmienia się cel i znaczenie przelanej krwi. Nie oczyszcza, ale kala, stanowi symbol okrucieństwa wojny i rzeźni - zasycha na ciele, wypełnia pamięć „ja” mówiącego. Widok rzeźniczych scen - mówiąc za Freudem - przynosi „życiu psychicznemu [twórcy - K.N.] w ciągu bardzo krótkiego czasu [...] silny przyrost bodźców”12, kumuluje do granic niewypowiedziane emocje, które znajdują ujście dopiero w otwartej przestrzeni - w lesie. Wykrzyczenie ich, wypowiedzenie tego, co wcześniej na siłę było tłumione, przynosi poecie ulgę. Bohater liryczny, który udaje się do lasu po oczyszczenie, chociaż sam nie czyni krzywdy zwierzętom, poczuwa się do odpowiedzialności za wyrządzone im przez rodzaj ludzki zło. Będąc bezpośrednim obserwatorem „czerwonego morza rzeźni”, nie mogąc stanąć w obronie praw niewinnych istot - zarówno zwierząt, jak i Żydów, niejako bierze ich cierpienie na siebie. Przestrzeń natury pełni natomiast funkcję absolutu, który otwiera się na ból człowieka i w pewnym sensie rozgrzesza go. Las, otaczając opieką i czułością ,ja” mówiące, współcierpi razem z nim. Przejmując ból poety na siebie, uwalnia go od złych emocji, oczyszcza wnętrze. Krzyk chwilowo zostaje zastąpiony w nim ciszą, czerwień krwi - zielenią natury, zakrwawione ręce - czystymi dłońmi, poczucie winy - spokojnym sumieniem, przymus mieszkania za murami rzeźni - złudzeniem upragnionej wolności i zakończenia trwającej wojny. Odnaleziony w naturze spokój i uzyskane rozgrzeszenie nie trwają jednak długo:

I oto strzał i łoskot w leszczynie pobliskiej

i człowiek z dubeltówką i zwierz we krwi śliskiej ${ }^{13}$.

O ile las otwiera się na człowieka i przyjmuje go, o tyle ten, odczuwając swoją wyższość nad przyrodą, posuwa się zdecydowanie za daleko i popada z nią nieustannie w konflikt. Ostatecznie rzeczywistość rzeźni, od której twórca próbuje uciec, dopada go na każdym kroku, powraca mimowolnie w najmniej niespodziewanych momentach, niekontrolowanie się powtarza, jakby już na zawsze poeta był na nią skazany. Wyobrażenia czy „ekologiczne marzenia” poety o dzikiej i „czystej” naturze, do której nie miał wcześniej dostępu, zostają szybko zweryfikowane i zaniechane. W lesie, oprócz upragnionego dostępu do przyrody, prawie zawsze spotyka myśliwego albo drwala, którzy swoimi działaniami ingerują w środowisko. Przestrzeń natury, zamiast być nienaruszoną i wspólną dla wszystkich, okazuje się miejscem zawłaszczonym przez człowieka. Ten - z perspektywy Śliwiaka - nie potrafi/nie chce przyjąć, „że jest po prostu jedną z wielu istot żywych zamieszkujących Ziemię, nieuprzywilejowanym elementem biosfery"14, ale przeciwnie: próbuje ją zdominować i urządzać po swojemu ${ }^{15}$. Autor Chityny pragnie zatarcia różnic między naturą a człowiekiem - chce ich

\footnotetext{
${ }^{11}$ Mirosław Wróbel, „Oczyszczenie”, w Encyklopedia katolicka, t. XIV: Nouet - Pastoralis Officii (Lublin: Towarzystwo Naukowe Katolickiego Uniwersytetu Lubelskiego Jana Pawła II, 2010), 296.

${ }^{12}$ Sigmund Freud, „Wykłady ze wstępu do psychoanalizy”, w Wykłady, przeł. Robert Reszke (Warszawa: Wydawnictwo KR, 2010), 258.

${ }^{13}$ Śliwiak, „Rondo”, 23.

${ }^{14}$ Fiedorczuk, Cyborg w ogrodzie, 53.

${ }^{15}$ Por. Justyna Tabaszewska, „Ekokrytyczna (samo)świadomość”, Teksty Drugie, nr 2 (2018): 12.
} 
współistnienia, wzajemnego zrozumienia albo - jak pisał Artur Sandauer, wskazując na wyraźnie obecną w utworach poety „problematykę bio- czy geologiczną” - „aktywnego kontaktu”, „utarcia” 6 .

\section{Wielkość i dobroczynność natury}

Śliwiak w swoich utworach przyjmuje postawę wglądu w naturę. Próbując opisać jej doznania i życie w czasach antropocenu, oddaje głos "pozaludzkim elementom przyrody”, tym samym spełniając ekokrytyczny „postulat mówienia w imieniu środowiska” ${ }^{17}$. Poeta w tomie Widnokres, w części Ziemia, umieścił składający się z trzech fragmentów utwór, nieprzypadkowo zatytułowany Oratorium, będący niejako podsumowaniem jego spostrzeżeń dotyczących zielonych przestrzeni. Tytuł wiersza najpierw wskazuje na „monumentalną formę muzyczną przeznaczoną na głosy solowe, chóry i orkiestrę"18 (w liryku Śliwiaka przemawia podmiot zbiorowy - chór drzew, który opisuje ich funkcjonowanie na poszczególnych etapach życia), następnie na miejsce kultu bóstw, „wspólnotowej lub indywidualnej modlitwy, zdobywania mądrości i cnót"19. W wierszu autora Chityny las nazwany „oratorium” spełniałby zatem funkcję przestrzeni sakralnej, byłby swego rodzaju godnym naśladowania absolutem, natura natomiast pojmowana jako „domena harmonii, niewinności i nienaruszonego piękna” pozostawałaby „w opozycji do tych aspektów kultury, które uważa się za zepsute, zwyrodniałe albo - odwołując się do języka teologii - upadłe"20.

W pierwszej części wiersza czytamy:

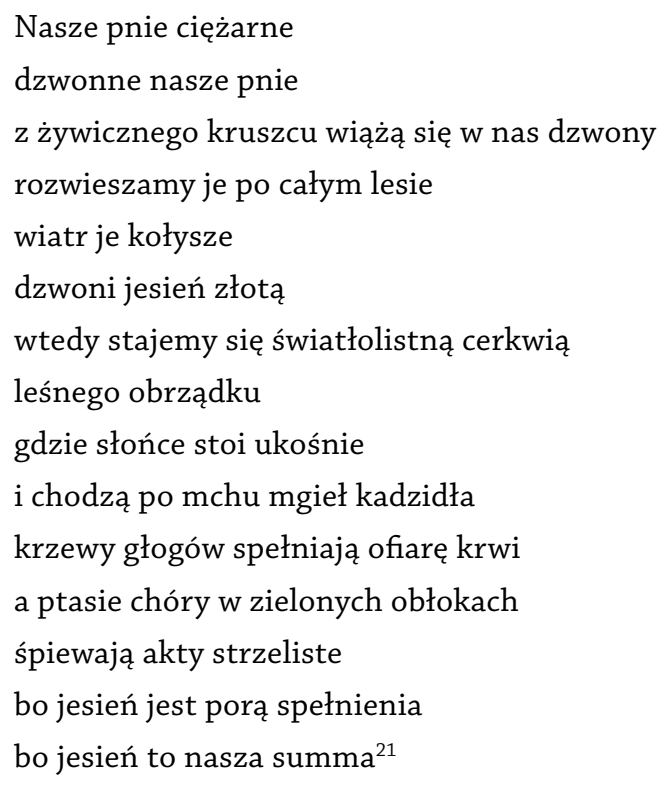

${ }^{16}$ Sandauer, „Poezja tragicznego ładu”, 482-483.

${ }^{17}$ Tabaszewska, „Wstęp”.

${ }^{18}$ Michał Głowiński, „Oratorium”, w Michał Głowiński, Teresa Kostkiewiczowa, Aleksandra Okopień-Sławińska, Janusz Sławiński, Słownik terminów literackich (Wrocław-Warszawa-Kraków: Zakład Narodowy im. Ossolińskich, 2007), 360.

${ }^{19}$ Waldemar Partyka, „Oratorium”, w Encyklopedia katolicka, t. XIV: Nouet - Pastoralis Officii (Lublin: (Lublin: Towarzystwo Naukowe Katolickiego Uniwersytetu Lubelskiego Jana Pawła II, 2010), 711.

${ }^{20}$ Fiedorczuk, Cyborg w ogrodzie, 41.

${ }^{21}$ Tadeusz Śliwiak, „Oratorium”, w Widnokres (Warszawa: Państwowy Instytut Wydawniczy, 1971), 111. 
Poeta, tworząc lirykę roli, udziela głosu tym, których pozbawiono podmiotowości. Aby pozwolić mówić drzewom w pierwszej osobie liczby mnogiej i tym samym w pełni przedstawić ich perspektywę widzenia, posługuje się w całym utworze personifikacją. Las bez człowieka jest wolny, może rządzić się własnymi prawami. Drzewa powracając do przeszłości, wspominają czas swojej potęgi i świetności. Ich odzwierciedleniem są „pnie ciężarne”. Symbolizują opór, mocarność, trwałość i twardość, tworzą - podążając za myślą Gastona Bachelarda - „wielkie obrazy mocy”, ucieleśniają „powołanie twardego męstwa”, są świadectwem wyrzeczeń i pokory („dławienia własnych porywów, wszelkich gnuśnych pokus zieloności i miękkości”). Pomimo wzbudzania wrażenia „siły, które nie myślą ulegać”22, w głębi pozostają istotami odczuwającymi, co odzwierciedlają z kolei „dzwonne” (dźwięczne) pnie. „W drzewie - pisał Manfred Lurker - zaplątuje się wiatr i zyskuje głos: drzewo stęka i jęczy, w jego wierzchołku coś szepcze i szemrze"23. Z dzwonkami na gałęziach drzew zostaje w utworze skojarzona wydzielana przez korę żywica. Podmiot mówiący, nazywając ją „kruszcem” sugeruje, że jest podobna do szlachetnych surowców. Nie bez powodu. O jej wartości świadczą bowiem jej lecznicze właściwości - służy do zabezpieczania wszelkich „ran drzewa”. Natura jest więc samowystarczalna, buduje oparcie sama w sobie. Chór drzew dwukrotnie zresztą powtarza: „nasze pnie”. Zaimek dzierżawczy ma podkreślić, że nie są one własnością człowieka. Przyroda odradza się, czuje się nieograniczona, żyje własnym rytmem, wyznaczanym przez pory roku. W dziewiczym lesie szczególnej celebracji zostaje poddana jesień. Co ciekawe, nie jest ona symbolem rozkwitania, nietrwałości, kruchości, przemijania, nieuchronnego zbliżania się do śmierci, ale staje się czasem wielkiego świętowania potęgi drzew i mocy, którą objawiają. Mircea Eliade napisał:

[...] drzewo jest pełne sił sakralnych dlatego, że jest pionowe, że rośnie, że traci liście i na nowo je odzyskuje, a więc regeneruje się („umiera” i „zmartwychwstaje”) nieskończoną ilość razy, że ma żywicę itd. Źródłem tych wszystkich uzasadnień jest prosta kontemplacja mistyczna drzewa jako „formy” i jako odmiany życia biologicznego. [...] Drzewo staje się święte na skutek swej mocy, tzn. dlatego, że objawia rzeczywistość pozaludzką, która ujawnia się człowiekowi w określonym kształcie, przynosząc owoce i periodycznie się odnawiając $c^{24}$.

Chór drzew zdradza czytającym utwór Śliwiaka nieodkryte dotąd tajemnice natury. Las, znajdując się poza działalnością człowieka, zamienia się w miejsce sacrum, w którym odbywają się cykliczne, święte obrzędy natury. Na tę okazję drzewa przybierają niezwykłego wyglądu. Przenika je metafizyczna jasność, dzięki której nie tylko stroją się w tradycyjne, jesienne barwy czerwieni, brązów, żółci, ale stają się „światłolistne”. Oto nieznana i niedostępna człowiekowi strona lasu, trudna do opisania - stąd też zastosowany przez poetę neologizm. Okazuje się, że leśny rytuał ma swój porządek i składa się ze stałych elementów, zaczerpniętych z katolickiej liturgii. Mgła zostaje skojarzona tu $\mathrm{z}$ dymem kadzidła, będącym objawem obecności bóstwa w zielonej przestrzeni; czerwone owoce ciernistego głogu po pierwsze z „ofiarą krwi” przelaną na krzyżu przez Chrystusa, symbolizującą jego cierpienie, po drugie - ze starotestamentowym obrzędem

\footnotetext{
${ }^{22}$ Gaston Bachelard, „Ziemia, wola, marzenia”, w Wyobraźnia poetycka. Wybór pism, wyboru dokonał Henryk Chudak, przeł. Henryk Chudak, Anna Tatarkiewicz, przedmowa Jan Błoński (Warszawa: Państwowy Instytut Wydawniczy, 1975), 227, 229-230.

${ }^{23}$ Manfred Lurker, „Uniwersalność symbolu drzewa”, w Przesłanie symboli w mitach, kulturach i religiach (Warszawa: Wydawnictwo Aletheia, 2011), 250.

${ }^{24}$ Mircea Eliade, „Roślinność: symbole i ryty odnowienia”, w Traktat o historii religii, tłum. Jan Wierusz Kowalski (Warszawa, Wydawnictwo Opus, 2009), 280-281.
} 
pokropienia krwią zwierzęcą, rytuałem mającym przebłagalny charakter; głos ptaków z wyśpiewywanymi i odmawianymi przez lud „aktami strzelistymi” - krótkimi wezwaniami do bóstw, świadczącymi o wybieganiu ku nim myśli „w celu nawiązania [...] duchowego kontaktu”25. Te ostatnie są wyśpiewywane „w zielonych obłokach” - w koronach drzew. Podmiot wskazuje na ich ważność - są pośrednikami między ziemią a niebem, im wyższe i potężniejsze, tym bardziej zbliżają do absolutu albo - jak pisał Mircea Eliade - stają się „siedzibą bóstwa”26.

Zielona przestrzeń w utworze Śliwiaka doskonale zna swoją wartość, broni się przed próbami zakłócenia jej spokoju i obowiązującego w niej porządku:

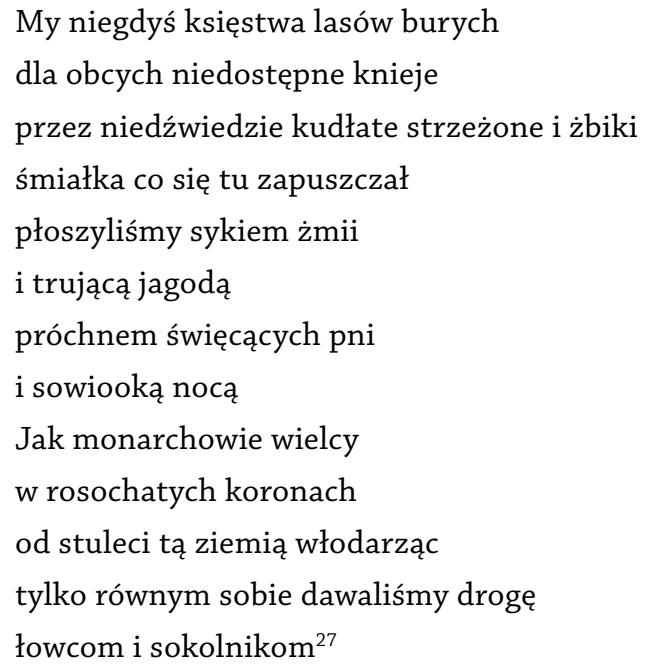

Drzewa, przemawiając z perspektywy współczesnej autorowi Kolczugi, nieustannie powracają do przeszłości. Nazywając siebie „monarchami wielkimi / w rosochatych koronach”, tworzącymi nienaruszalne „księstwa lasów burych”, wracają do czasów, w których były podziwiane, szanowane i czczone - postrzegane jako „przewyższające wszelkie inne istoty żywe” ${ }^{28}$. Ich wielkość stanowiła dla człowieka z jednej strony „zachętę do hartu ducha”, „wspaniały obraz uzasadnionej dumy”, z drugiej - ujawniała ich kojącą moc, przynosiła ulgę i uspokojenie. „Czyż drzewo nie wstrzymuje nawet przepływającej chmurki?” - pyta w Wyobraźni poetyckiej Gaston Bachelard, podkreślając jego nieograniczoną, boską $\operatorname{moc}^{29}$. Lasy postrzegano wówczas jako przestrzeń tajemniczą, potężną, nieujarzmioną, zamkniętą dla intruzów, strzeżoną przez dzikie zwierzęta i osobliwe gatunki roślin, ale też hojną, dobroczynną, zapewniającą drugiemu schronienie i odpoczynek. Przyroda - zgodnie z boskim życzeniem z Księgi Rodzaju - była poddana człowiekowi, ale w zupełnie innym wymiarze:

W naturze drzewa objawia się potęga życia. Pod sękatymi pniami, które przeżyły niejedno pokolenie, ludzie uświadamiali sobie krótkotrwałość własnego życia. W postaci owoców brali od drzewa siłę życiową,

\footnotetext{
${ }^{25}$ Józef Zbiciak, „Akt strzelisty”, w Encyklopedia katolicka, t. 1: A i $\Omega$ - Baptyści, red. Feliks Gryglewicz, Romuald Łukaszyk, Zygmunt Sułowski (Lublin: Towarzystwo Naukowe Katolickiego Uniwersytetu Lubelskiego, 1973), 275.

${ }^{26}$ Eliade, „Roślinność: symbole i ryty odnowienia:”, 283.

${ }^{27}$ Śliwiak, „Oratorium”, 111-112.

${ }^{28}$ Lurker, „Uniwersalność symbolu drzewa”, 239.

${ }^{29}$ Bachelard, „Ziemia, wola, marzenia”, 229-230.
} 
w liściach i kwiatach szukali lekarstwa na najrozmaitsze choroby, a tworzące dach gałęzie posłużyły im za wzór namiotu i domu. W kwitnieniu i owocowaniu, w corocznym umieraniu i odradzaniu się przeczuwano działanie wyższej potęgi, która była dla człowieka nadzieją na przezwyciężenie śmierci ${ }^{30}$.

\section{Kryzys natury}

Nadmierna dobroczynność natury finalnie doprowadziła nie do wypracowania więzi pomiędzy przyrodą a człowiekiem, ale do jego „wyemancypowania się spod jej rządów”" ${ }^{1}$, wkroczenia na terytorium zielonej przestrzeni i jej ujarzmienia. Las, który rządził się własnymi prawami, zostaje teraz poddany ludzkiej hegemonii. Dotychczasowa perspektywa biocentryczna wyraźnie zmierza w kierunku antropocentrycznej. W drugiej części Oratorium czytamy:

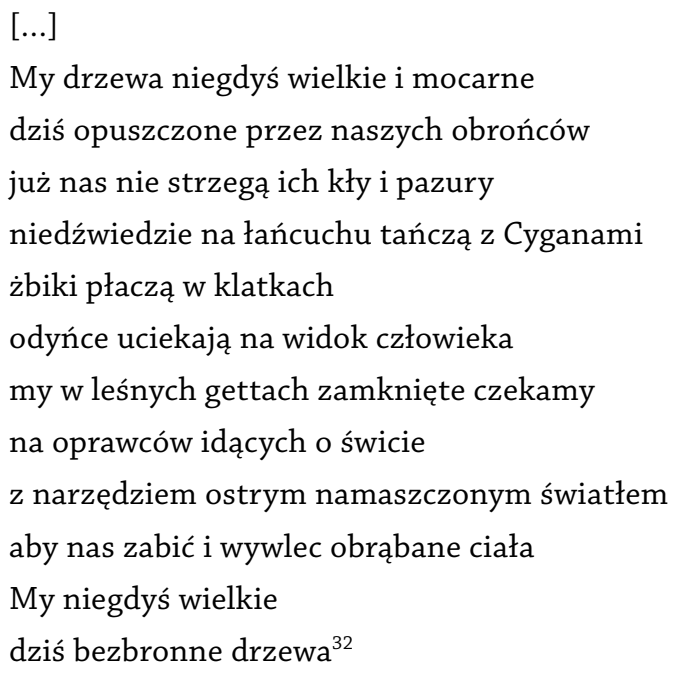

Chór drzew, opisując zmiany, jakie zaszły w zielonej przestrzeni, zestawia przeszłość z teraźniejszością. Ich dawna potęga przemienia się w bezbronność. Dewastacja lasu w utworze Śliwiaka rozpoczyna się jednak nie od niszczenia flory, ale fauny. Udzielający głosu przyrodzie poeta, który spędził swoje dzieciństwo w miejskiej rzeźni, w sposób szczególny jest uwrażliwiony na cierpienie i niewłaściwe czy nierówne traktowanie zwierząt. Leśne stworzenia zamiast cieszyć się wolnością w zielonej przestrzeni, w której miały swoje określone miejsce, zostają przystosowane przez człowieka do życia niezgodnego z ich naturą. Ujarzmianie dzikości zmierza do usunięcia wyraźnie zaznaczonej w poprzedniej strofie utworu bariery istniejącej pomiędzy ludźmi a zwierzętami, która dotąd broniła las przed intruzami. Dopiero pokonanie „groźnej «zwierzęcości»”, lęku i poczucia zagrożenia, umożliwia pełne wejście człowieka do zielonej przestrzeni. Stojące wcześniej na jej warcie niedźwiedzie, żbiki i odyńce zostają poddane tresurze i ubezwłasnowolnieniu. W efekcie - pisał Tadeusz Sławek - z jednej strony „zwierzę «człowieczeje», traci swą spontaniczność, odruchowość”, z drugiej jednak - jego „skulturalizowanie” okazuje się niemożliwe ${ }^{33}$. O ile w wierszu autora Wid-

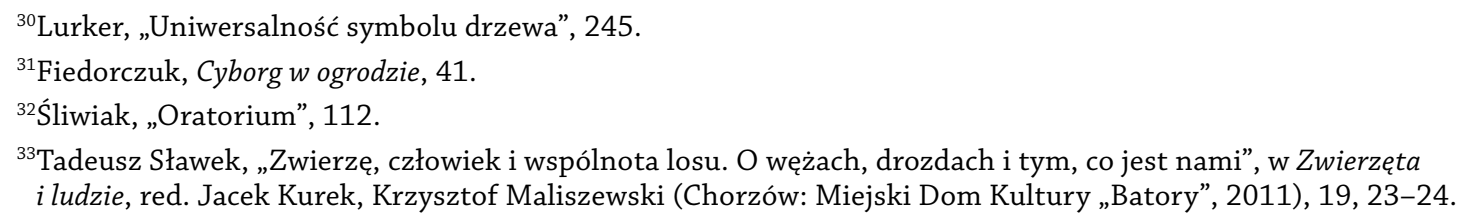


nokresu niedźwiedzie dostosowują się do sytuacji i „na łańcuchu tańczą”, o tyle inne stworzenia nie zgadzają się na swój los, cierpią i próbują się bronić: „żbiki płaczą w klatkach”, „odyńce uciekają na widok człowieka”. Lasy bez dzikich zwierząt zmieniają się ze „światłolistnych cerkwi” w zamknięte „leśne getta”, w których drzewa nie mają już na nic wpływu, nad którymi władzę przejmują drwale. Chór drzew wie, o jakiej porze przychodzą i w jakim celu. Świadomy czekającej go wcześniej czy później śmierci, przygotowany na nią każdego poranka, nazywa ich wprost oprawcami. Słowo to konotuje z innymi, mocniejszymi określeniami: barbarzyńcy, kaci, dręczyciele, mordercy. W innym wierszu autora Widnokresu drzewo mówi: „z siekierą na ramieniu / idzie człowiek przez las / boję się jego oczu / boję się jego pomysłów"34. To ludzie, a nie natura okazują się nieprzewidywalni. Kto przykłada siekierę do drzewa, wykorzenia je, radykalnie niszczy, przeznacza na zagładę 35 . Już samo trzymanie w ręku narzędzi służących do wycinki nadaje wyrąbującemu nieograniczoną władzę nad lasem. Kiedy pojawia się kat - pisał poeta w tomie Widnokres - „nim pierwszy topór w pierwszy pień uderzy”, natura gaśnie, więdnie, zmienia swoje barwy („ciemnieje zieleń mech swą miękkość traci”), nadaje ostrzegawcze sygnały („ptak ponad gniazdem kołuje spłoszony”, „wiatr się zrywa”, „w źródłach rdzawy pojawia się naciek”, „świecą pnie spróchniałe”), płoszy się i ukrywa („głębiej się chowa rudy lis w swej jamie”, „ślepe sowy dziób chowają w pierze / kryją swą bladość pod liściem podbiały”), resztkami sił próbuje bronić swojego terytorium („ścieżki zarasta blekot i pokrzywa”). Drzewa natomiast, wyczuwając zagrożenie, „w pniach twardnieją”. Ich kolejne warstwy, pragnąc uniknąć zagłady, jednoczą się ze sobą, splatają, robią wszystko, aby utrudnić ich rozpruwanie, rozrywanie, ranienie. Drzewo - twierdził Gaston Bachelard - „zwija się w sęki, aby znaleźć oparcie nie w glebie, żyznej i pulchnej, lecz w sobie samym, w tej dodatkowej twardości, jaką jest sękaty pień. Twardnieje, by trwać" ${ }^{\prime 6}$. Oto przyjęta, ale nie zawsze skuteczna linia obrony. Ostatecznie bowiem, kiedy przychodzi drwal, natura pozostaje wobec niego bezbronna. W innym wierszu Śliwiaka czytamy:

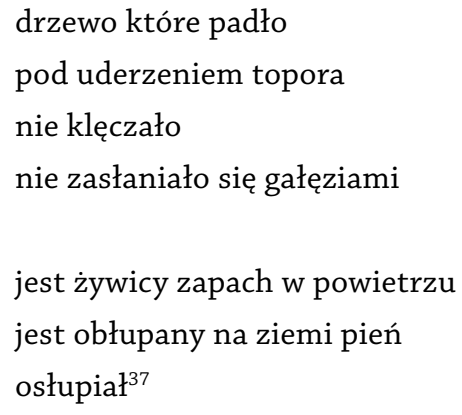

Drzewa umierają, stojąc. Oto dramat, z którym się mierzą. Nie uniżają się przed swoimi oprawcami ani nie proszą o darowanie im życia. Pozostają dumne, pokornie przyjmują los, na który zostały skazane. Ich chór w ostatniej strofie Oratorium zresztą mówi: „nie wiemy czym jest ucieczka / znamy dla siebie tylko jedną drogę / wzwyż do światła"38. Celem ich trwania nie jest zatem poddanie się ścięciu, ale budowanie swojej mocy, podążanie w stronę „niebiańskich sfer kosmicznych”, metafizycznych, sakralnych. Pozostałością po potędze drzewa jest z kolei „obłupany [...]

\footnotetext{
${ }^{34}$ Tadeusz Śliwiak, „Drzewo”, w Solizman (Warszawa: Państwowy Instytut Wydawniczy, 1981), 26.

${ }^{35}$ Władysław Kopaliński, Topór, w Słownik symboli (Warszawa: „Wiedza Powszechna”, 1990), 428.

${ }^{36}$ Bachelard, „Ziemia, wola, marzenia”, 225.

${ }^{37}$ Tadeusz Śliwiak, „Osłupienie”, w Żywica (Warszawa: Czytelnik, 1964), 62.

${ }^{38}$ Śliwiak, „Oratorium”, 113.
} 
pień”. Oszołomienie śmiercią jego najistotniejszej części siebie podmiot liryczny określa „osłupieniem”, a więc - podając za Witoldem Doroszewskim - „stanięciem jak wrytym, znieruchomieniem ze zdumienia, z przerażenia, zdrętwieniem". Peter Wohlleben, poddając obserwacji zieloną przestrzeń, nie bez powodu pyta: „A gdy drzewo zostanie ścięte? Czy wtedy jest martwe? Co się dzieje ze [...] kilkusetletnim pniakiem [...]? Czy jest on drzewem, a jeśli nie, to czym w takim razie jest?" ${ }^{39}$. Pień po uderzeniu siekiery jest poraniony, staje się samotny, musi od nowa zdefiniować siebie i określić swoją rolę w zielonej przestrzeni. „Czy takie pnie są zatem młodymi drzewami, czy też raczej tak naprawdę tysiącletnimi starcami?” - zastanawia się dalej autor Nieznanych więzów natury. Henry D. Thoreau w jednym ze swoich esejów pisał: „Właściciel siekiery, wypuszczając z ręki jej stylisko, oświadczył, że to jego oczko w głowie; ale zwróciłem ją bardziej naostrzoną, aniżeli otrzymałem" ${ }^{40}$. W „leśnym gettcie” staje się ona głównym narzędziem zbrodni, każde kolejne wycięte drzewo dodaje jej natomiast więcej poręczności. Znakiem dokonującej się w danym momencie zagłady lasu jest także zapach żywicy, który uwalnia się z każdym uderzeniem topo$\mathrm{ra}^{41}$. W miejscach, gdzie ów zapach jest intensywniejszy, tam dokonała się śmierć natury. Śliwiak w utworze Ostupienie skonstatował: „woń żywicy wiedzie / z lasu do tartaku / z tartaku do lasu”. Oto droga krzyżowa, którą przechodzą drzewa.

\title{
Martwa natura
}

Deforestacja, którą tak często porusza w swoich utworach Tadeusz Śliwiak, nasila się wraz z rozwojem cywilizacji. To, co stanowi dobro dla człowieka i staje się jego codziennością, jest zupełnie inaczej odbierane przez samą przyrodę:

\author{
Wiążą nas w tratwy \\ pławią wielką rzeką \\ oto jest nasza droga do piekła tartaku \\ gdzie piły rozpędzone szarpią nasze włókna \\ i tną na sztuki nasze piękne ciała \\ w ułożonych deskach wiatr nas nie poznaje \\ wióry nasze rozwiewa jak uschnięte liście \\ Obedrą nas z urody naszej \\ obdarzą swoją wyobraźnią piękna \\ wygładzą sęki \\ namaszczą świecidłem ${ }^{42}$
}

\footnotetext{
${ }^{39}$ Peter Wohlleben, Sekretne życie drzew, tłum. Ewa Kochanowska-Szlęzak (Kraków: Wydawnictwo Otwarte, 2017), 88.

${ }^{40}$ Henry David Thoreau, Walden, czyli życie w lesie, przekład, przedmowa, przypisy Halina Cieplińska (Warszawa, 1991, 66.

${ }^{41}$ Śliwiak w swoich utworach przywołuje także inne narzędzie, którym posługują się ścinający drzewa - piłę: „Przyszli / z ramion topory zdjęli / ujęli w ręce swe zębate piły / tą stalą wyostrzoną czynią wiele światła” czytamy w wierszu W środku lasu (w: Tadeusz Śliwiak, Czytanie mrowiska (Warszawa: Czytelnik 1969), 27); „Leżymy powaleni / na suchym mchu lasu / pień olbrzym / i ja / Patrzę na opartą o pień drzewa piłę / pokazuje zęby // Jutro wrócą tu drwale" - napisał poeta w utworze Człowiek w lesie (w: Tadeusz Śliwiak, Wyspa galerników (Kraków: Wydawnictwo Literackie, 1962), 13).

${ }^{42}$ Śliwiak, „Oratorium”, 112-113.
} 
We fragmencie tym wybrzmiewa mocny podział na dwie kategorie gramatyczne: oni - my. Po stronie pierwszej znajduje się kultura na czele z człowiekiem, po drugiej - natura. Ta staje się w pełni zawłaszczona przez ludzi, którzy żyją w przekonaniu, że - jak pisała Fiedorczuk - jej „jedynym zadaniem [...] jest służenie człowiekowi, albowiem postęp technologiczny i rozwój kapitalizmu są dobre same w sobie, a natura znajdzie sposób, aby się do tego dostosować" ${ }^{\prime 3}$. Podmiot liryczny przedstawia w tym temacie swój własny punkt widzenia. Próbuje uświadomić oprawcom, że drzewa są również istotami cielesnymi. Wtóruje im Śliwiak, który dostrzega i opisuje cechy fizjologiczne drzew:

\section{[...] w drzewie \\ pod sepią kory jest krew biała \\ dostać ją znaczy drzewołomnie \\ przecinać struny naprężone \\ zieleń jutrzejszą gasząc nagle ${ }^{44}$}

Kora jest tu odpowiednikiem skóry, „krew biała” - wyciekającej z niej żywicy, kojarzące się z żyłami „struny naprężone” - twardniejących sęków. Każde uderzenie w nie toporem to zadanie drzewom dotkliwych ran, wyzucie z nich życia. W Oratorium przypominają one, że konkretne elementy składające się na ich budowę znaczą coś więcej. Manfred Lurker pisał: „Gałęzie reprezentują formę i ideę, zewnętrzna kora staje się symbolem cielesności, przestrzenie znane z geografii jawią się jako listowie, a gwiazdy jako kwiaty; płynący naczyniami drzewa

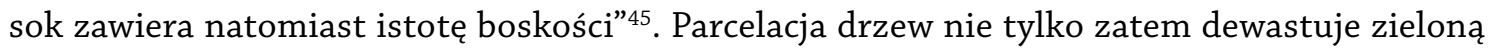
przestrzeń, zmienia jej pierwotne przeznaczenie, ale także pozbawia je jako całości istotnych znaczeń symbolicznych. Traktowane przedmiotowo stają się ofiarami przemocy. Czynności na nich wykonywane są ekspresywne i brutalne: „wiążą nas”, „pławią”, „szarpią”, „tną" - skarżą się drzewa. Ich chór zamiast - jak chciał autor Wyobraźni poetyckiej - „wysoko wznosić swą powietrzną koronę, swe uskrzydlone listowie"46, staje się obdartym ze swojego pierwotnego piękna „ułożonymi deskami”. Ingerencja człowieka w naturę drzew na tyle je przekształca, że przemieniają się one w nowe twory, nierozpoznawalne także w samej przestrzeni przyrody. Dotąd współpracujący z nimi wiatr przeobraża się w niewspomagający ich żywioł. „Wióry”, które rozwiewa są dla niego tylko odpadami, resztkami wytworzonymi przez człowieka. Tak zachowujący się żywioł stanowi dla drzew wyraźny znak ich przemijania, niestałości, niepokoju $^{47}$ - uświadamia ogrom wyrządzonej krzywdy i zniszczenia. Chór drzew zwraca uwagę na rozbieżność punktów widzenia natury i kultury, szczególnie jeśli chodzi o pojmowanie kategorii piękna. Człowiek dostrzega wartości estetyczne głównie w „martwej naturze”, która została wytworzona dzięki jego umiejętnościom. Pokonują one nawet kiedyś niepojętą potęgę przyrody. Człowiek, stosując różne zabiegi ingerujące w nią, odchodzi „od animistycznego i organicystycznego rozumienia natury" ${ }^{\prime 8}$, zmierza w stronę kapitalizmu. Uśmiercając ją, czerpie konkretne zyski. Śliwiak o dewastującej naturę ludzkiej działalności dalej napisał:

\footnotetext{
${ }^{43}$ Fiedorczuk, Cyborg w ogrodzie, 41.

${ }^{44}$ Tadeusz Śliwiak, ${ }^{* * *}[$ Idąc przez śniegi...], w Ruchoma przystań (Kraków: Wydawnictwo Literackie, 1971), 61.

${ }^{45}$ Lurker, „Uniwersalność symbolu drzewa, 243.

${ }^{46}$ Bachelard, „Ziemia, wola, marzenia”, 230.

${ }^{47}$ Por. Władysław Kopaliński, Wiatr, w Słownik symboli (Warszawa: „Wiedza Powszechna”, 1990), 453.

${ }^{48}$ Ewa Domańska, „Humanistyka ekologiczna”, Teksty Drugie, nr 1-2 (2013): 18-19.
} 


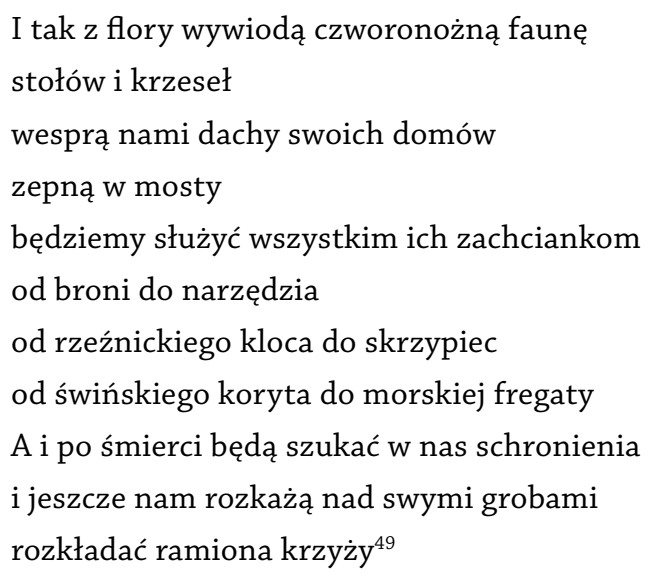

Istota ludzka zostaje przedstawiona jako kreator rzeczywistości. Przejmuje boską rolę stwarzania świata na swoich warunkach. Ingerencja człowieka radykalnie zmienia charakter przyrody: „z flory” powstaje „Czworonożna fauna”. Dochodzi tutaj do nieodwracalnego procesu zmiany natury drzew, nieakceptowanej przez nie transgresji. Tę przekształcającą zieloną przestrzeń działalność człowieka Ernst Jünger próbuje wyjaśnić następująco: „czujemy się "W drewnie» naprawdę u siebie" ${ }^{50}$, dlatego za uzasadnione uważa on eksploatowanie lasu w celach ułatwiających ludzką egzystencję. Przekształcone drzewa, przyjmując teraz postać stołów, krzeseł, dachów, mostów, skrzypiec, ale także trumien czy krzyży itp. - podążając za myślą eseisty - stają się nieodzowną częścią nie tylko kultury, ale także mogą trwać dalej, nawet wtedy, kiedy umiera człowiek. Więcej: transgresja, którą przechodzą, pozwala na wydobycie z nich tego, co najistotniejsze. Tam, gdzie „buduje się z drewna” - kontynuował Jünger - „uwidacznia się nam prawdziwe życie [...], jego leśny i drzewny duch, jego leśny czar, którego nawet topór nie niszczy" ${ }^{51}$. Tę wartość ukrytą w otaczających przedmiotach docenia także Śliwiak. Wiedząc, że jest w nich zawarte coś więcej, pragnie je poznać. W tym celu uruchamia wszystkie swoje zmysły. Obcując z rzeczami, dotyka ich, wącha, przygląda się im, analizuje, poszukuje w nich pierwotnej natury:

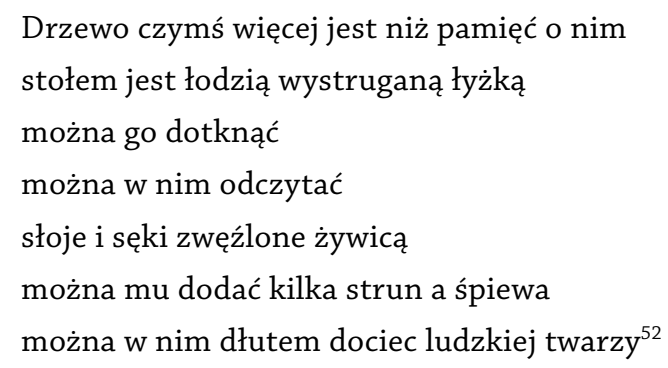

Wnikanie w głąb rzeczy zrobionych z drewna, pozwala odkryć historię drzew, skłania do zadania pytania, które poeta czterokrotnie stawia w liryku Rozdarcia, kiedy ogląda wystawę mebli w Kalwarii Zebrzydowskiej: „Co to za las?”. Zauważając, że jest przestrzenią jednego, wielkiego braku,

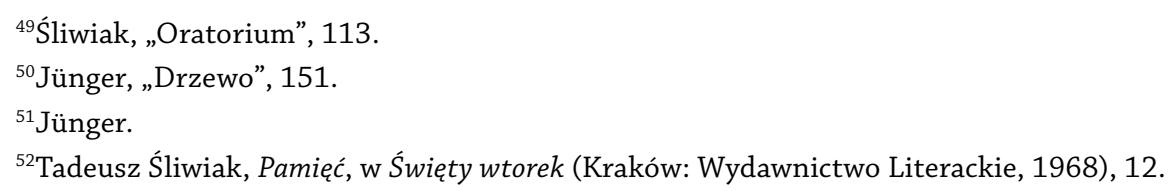


z przykrością odpowiada: „to las co odszedł / w stronę ludzi i chłodnych zwierciadeł”"53. Ale człowiek, wykorzystując do realizacji swoich celów zieloną przestrzeń, popada również w skrajności. $Z$ drzewa, oprócz rzeczy użytecznych, powstają te służące do zabijania, ułatwiające czynienie zła „broń” i „rzeźniczy klocek”. Drzewa przystosowane do pełnienia funkcji tych przedmiotów stają się nie tylko świadkiem dramatycznych scen zagłady, ale także wbrew sobie, zostają przekształcone w narzędzia zbrodni, mają swój udział w cierpieniach niewinnych istot.

\section{Odpowiedzialność za naturę}

Tadeusz Śliwiak, pisząc o dewastowaniu przyrody, nie może odejść od doświadczeń wyniesionych z dzieciństwa. Tak jak w miejskiej rzeźni we Lwowie miała miejsce śmierć Żydów i zwierząt, tak zdominowana przez człowieka zielona przestrzeń zostaje określona przez poetę „leśnym gettem", w którym ostatecznie dokonuje się unicestwienie natury. I jedna, i druga zagłada żyją wciąż w poecie, są jątrzącą się raną, nieprzepracowaną traumą: „stoję tu / po wielu przykładach / nie oswoiłem w sobie / mieszkającej śmierci” "54, „patrzę w las - widzę drzewo całe w łuskach siekier"55 - wyznaje. Autor Rajskich wron, udzielając głosu drzewom, opisuje kolejne etapy ich życia. Beztroska kończy się z chwilą wkroczenia w zieloną przestrzeń człowieka. Ten, zamiast korzystać z dobrodziejstw przyrody, współpracować z nią czy wspierać, obmyśla plan jej przeobrażenia z natury pierwotnej w drugą, a nawet trzecią naturę ${ }^{56}$. I tak rosnące beztrosko potężne drzewa stają się najpierw własnością człowieka, od których zaczyna zależeć ich dalsze istnienie, następnie zostają przez jego działalność i umiejętności przetworzone najpierw $\mathrm{w}$ „ułożone deski”, potem w rozmaite przedmioty. $Z$ jednej strony służą one jako konieczne rzeczy codziennego użytku, z drugiej - przysługują się złu, temu, co moralnie przekracza wszelkie granice. Więcej: drzewa same dla siebie stają się oprawcami, gdyż to zazwyczaj z drewna wykonana jest rękojeść siekiery i piły. Poeta na każdym kroku dostrzega dramatyczne skutki działalności człowieka: „Dłuższa jest teraz / droga wiewiórki / z drzewa na drzewo / więcej jest teraz nieba / zstępującego w las” - pisał w Osłupieniu; „Tu pozostanie / pusty słup powietrza / nie obsiądą go ptaki / i zwierz się nie otrze”; „ustaną korzenie / pień okaleczony / zamknie się w sobie / licząc stygnące słoje" - przewiduje w wierszu W środku lasu. Śliwiak, uznając ludzi za głównych sprawców kryzysu natury, zadaje istotne pytanie: „czy człowiek zdusi winę w sobie / ofiarą ognia i potrzebą / stołu i łodzi z parą wioseł”57. Poeta, będąc świadomy, że sam korzysta z kultury kosztem natury i pośrednio staje się także dręczycielem drzew, wie, że nie może mieć pretensji do drwali. Więcej: staje niejako w ich obronie: „poznałem najwyżej pięciu sześciu drwali / to dobrzy ludzie / nie mam im nic do zarzucenia"58. Autor Widnokresu należy jednak

\footnotetext{
${ }^{53}$ Tadeusz Śliwiak, „Rozdarcia”, w Widnokres (Warszawa: Państwowy Instytut Wydawniczy, 1971), 110.

${ }^{54}$ Śliwiak, „Osłupienie”, 62.

${ }^{55}$ Tadeusz Śliwiak, „Igła”, w Dotyk (Warszawa: Młodzieżowa Agencja Wydawnicza, 1989), 68.

${ }^{56}$ Julia Fiedorczuk wyjaśniała: „Druga natura to natura przetworzona przez człowieka na skutek prowadzenia upraw, tworzenia systemów irygacyjnych czy budowania tam. Koncepcja trzeciej natury wiąże się z rozwojem technologii obrazowania i informatyki - jest to natura będąca wynikiem technologicznej reprodukcji. [...] wszystkie te pojęcia, pierwotna natura, druga natura i trzecia natura, mają sens tylko w kulturze, która silnie przeciwstawia sobie domeny natury i kultury, zaliczając istoty ludzkie do kultury i tym samym traktując wszelkie ich działania jako nienaturalne". Fiedorczuk, Cyborg w ogrodzie, 43-44.

${ }^{57}$ Śliwiak, ${ }^{* * *}[$ Idąc przez śniegi...], 61.

${ }^{58}$ Śliwiak, „Osłupienie”, 62.
} 
do tych, którzy poczuwają się do odpowiedzialności za środowisko naturalne, którzy uważają, że owa wina - ze względu na przynależność do rodzaju ludzkiego - na nich właśnie ciąży. Sam chór drzew z utworu Oratorium nazywa zresztą twórcę, pomimo że „pisze [on - K.N.) na papierze zaczerpniętym” z nich, „kronikarzem [...] słojów i spękanej kory”, obrońcą „poezji lasu" ${ }^{\prime 59}$. Autor Dotyku, ujmując w swoich wierszach cierpienie natury, pokazując dotkliwe skutki jej dewastowania, pragnie udzielać jej głosu albo mówić w jej imieniu. Stara się chociaż w ten sposób złagodzić wyrządzone jej krzywdy, konflikt pomiędzy nią a człowiekiem. Kiedy natomiast w tomiku Kolczuga pisze o „Dantym tartaków”, który siedzi „na wysokiej górze / usypanej z trocin" ${ }^{\prime 0} \mathrm{i}$ opłakuje las, ma na myśli przede wszystkim samego siebie.

\footnotetext{
${ }^{59}$ Śliwiak, „Oratorium”, 113.

${ }^{60}$ Tadeusz Śliwiak, „Dante”, w Kolczuga (Warszawa: Ludowa Spółdzielnia Wydawnicza, 1989), 68.
}

\section{Bibliografia}

Bachelard, Gaston. „Ziemia, wola, marzenia”. W Wyobraźnia poetycka. Wybór pism. Wyboru dokonał Henryk Chudak. Przetłumaczone przez Henryk Chudak, Anna Tatarkiewicz. Przedmowa Jan Błoński, 224-297, Warszawa: Państwowy Instytut Wydawniczy, 1975.

Bennett, Jill. „Wnętrza, zewnętrza: trauma, afekt i sztuka”. Przetłumaczone przez Anna Kowalcze-Pawlik, Tomasz Bilczewski. W Pamięć i afekty. Zredagowane przez Zofia Budrewicz, Roma Sendyka i Ryszard Nycz, 145-179. Warszawa: Instytut Badań Literackich PAN, 2014.

Domańska, Ewa. „Humanistyka ekologiczna”. Teksty Drugie nr 1-2 (2013): 18-19.

Eliade, Mircea. „Roślinność: symbole i ryty odnowienia”. W Traktat o historii religii. Przetłumaczone przez Jan Wierusz Kowalski, 277-341. Warszawa, Wydawnictwo Opus, 2009.

Fiedorczuk, Julia. Cyborg w ogrodzie. Wprowadzenie do ekokrytyki. Gdańsk: Wydawnictwo Naukowe Katedra, 2015.

Freud, Sigmund. „Wykłady ze wstępu do psychoanalizy”. W Wykłady. Przetłumaczone przez Robert Reszke. Warszawa: Wydawnictwo KR, 2010.
Głowiński, Michał. „Oratorium”. W Michał Głowiński, Teresa Kostkiewiczowa, Aleksandra Okopień-Sławińska i Janusz Sławiński, Słownik terminów literackich, 360. WrocławWarszawa-Kraków: Zakład Narodowy im. Ossolińskich, 2007.

Juchniewicz, Andrzej. „Z czyśćca na Parnas”. Śląsk, nr 5 (2020): 63.

Jünger, Ernst. „Drzewo”. W Wybór esejów o słowach $i$ drzewach. Wybrane i przetłumaczone przez Bogdan Baran, 139156. Warszawa: Wydawnictwo Aletheia, 2017.

Kopaliński, Władysław. Topór. W Słownik symboli, 428. Warszawa: „Wiedza Powszechna”, 1990.

Kopaliński, Władysław. Wiatr. W Słownik symboli, 453. Warszawa: „Wiedza Powszechna”, 1990.

Kuncewicz, Piotr. „Tadeusz Śliwiak”. W Agonia i nadzieja. T. 3: Poezja polska od 1956, 238242. Warszawa: Graf-Punkt-Polska Oficyna Wydawnicza „BGW”, 1994.

Lurker, Manfred. „Uniwersalność symbolu drzewa”. W Przesłanie symboli w mitach, kulturach i religiach. Warszawa: Wydawnictwo Aletheia, 2011. 239-259. 
Niesporek, Katarzyna. „Zwierzęta i ludzie. O Poemacie o miejskiej rzeźni Tadeusza Śliwiaka”. Porównania, nr 2 (2021) [w druku].

Partyka, Waldemar. „Oratorium”. W Encyklopedia katolicka. T. XIV: Nouet-Pastoralis Officii, 711. Lublin: Towarzystwo Naukowe Katolickiego Uniwersytetu Lubelskiego Jana Pawła II, 2010.

Pieńkosz, Konstanty. Świat nadziei paradoksalnej. W Tadeusz Śliwiak. Koń maści muzycznej. Wstęp i wybór Konstanty Pieńkosz, 5-13. Kraków: Wydawnictwo Literackie, 1986.

Sandauer, Artur. „Poezja tragicznego ładu (Rzecz o Tadeuszu Śliwiaku)”. W Zebrane pisma krytyczne. Studia o literaturze wspótczesnej, 467-483. Warszawa: Państwowy Instytut Wydawniczy, 1981.

Sławek, Tadeusz. „Zwierzę, człowiek i wspólnota losu. O wężach, drozdach i tym, co jest nami”. W Zwierzęta i ludzie. Zredagowane przez Jacek Kurek, Krzysztof Maliszewski, 19-30. Chorzów: Miejski Dom Kultury „Batory”, 2011.

Sobolczyk, Piotr. „Ty jesteś krowa a ja Żyd. Tadeusza Śliwiaka Holocaust zwierząt". Pogranicza, nr 5 (2009): 28-40.

Śliwiak, Tadeusz. ${ }^{* * *[I d a ̨ c ~ p r z e z ~ s ́ n i e g i . . .] . ~}$ W Ruchoma przystań, 61. Kraków: Wydawnictwo Literackie, 1971.

- - -. Człowiek w lesie. W Wyspa galerników, 1213. Kraków: Wydawnictwo Literackie, 1962.

- - -. „Dante”. Kolczuga, 68. Warszawa: Ludowa Spółdzielnia Wydawnicza, 1989.

- - -. „Drzewo”. W Solizman, 26. Warszawa: Państwowy Instytut Wydawniczy, 1981.

- - -. „Igła”. W Dotyk, 68. Warszawa:

Młodzieżowa Agencja Wydawnicza, 1989.

- - -. „Oratorium”. W Widnokres. Warszawa: Państwowy Instytut Wydawniczy, 1971.
- - -. „Osłupienie”. W Żywica, 62. Warszawa: Czytelnik, 1964.

- - -. Pamięć. W Święty wtorek, 12. Kraków: Wydawnictwo Literackie, 1968.

- - -. „Rondo”. W Poemat o miejskiej rzeźni, 23. Kraków: Wydawnictwo Literackie, 1965.

- - -. „Rozdarcia”. W Widnokres, 110. Warszawa: Państwowy Instytut Wydawniczy, 1971.

- - -. W środku lasu, 26-27. W Czytanie mrowiska. Warszawa: Czytelnik 1969.

- - -. „Wstęp”. W Poezje wybrane. Wyboru dokonał i wstępem opatrzył autor, 5-11. Warszawa: Ludowa Spółdzielnia Wydawnicza, 1975.

Tabaszewska, Justyna. „Ekokrytyczna (samo) świadomość". Teksty Drugie, nr 2 (2018): 7-16.

Thoreau, Henry David. Walden, czyli życie w lesie. Przekład, przedmowa, przypisy Halina Cieplińska. Warszawa, 1991 (w katalogu BN nie znalazłam książki z tego roku)

Wohlleben, Peter. Sekretne życie drzew. Przetłumaczone przez Ewa KochanowskaSzlęzak. Kraków: Wydawnictwo Otwarte, 2017).

Wróbel, Mirosław. „Oczyszczenie”. W Encyklopedia katolicka. T. XIV: NouetPastoralis Officii, 296. Lublin: Towarzystwo Naukowe Katolickiego Uniwersytetu Lubelskiego Jana Pawła II, 2010.

Zbiciak, Józef. „Akt strzelisty”. W Encyklopedia katolicka. T. 1: A i $\Omega$-Baptyści. Zredagowane przez Feliks Gryglewicz, Romuald Łukaszyk i Zygmunt Sułowski, 275. Lublin: Towarzystwo Naukowe Katolickiego Uniwersytetu Lubelskiego, 1973). 


\title{
SŁOWA KLUCZOWE:
}

\author{
ORATORIUM
}

\section{natura}

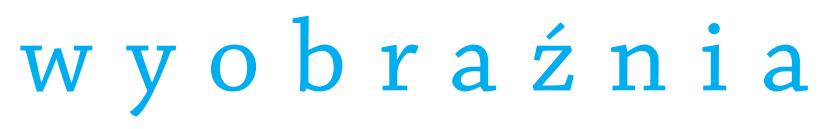

\begin{abstract}
AbSTRAKT:
Przedmiotem szkicu jest przyjrzenie się ekologicznej wyobraźni zapomnianego poety pokolenia'56 Tadeusza Śliwiaka oraz interpretacja jego wiersza Oratorium. Utwór ten stanowi podsumowanie spostrzeżeń poety dotyczących zielonych przestrzeni. Autor w swoich lirykach zauważa, że o ile natura otwiera się na człowieka i przyjmuje go, o tyle ten, odczuwając swoją wyższość nad przyrodą, posuwa się zdecydowanie za daleko i popada z nią nieustannie w konflikt. Przestrzeń natury, zamiast być nienaruszoną i wspólną dla wszystkich, okazuje się miejscem zawłaszczonym przez człowieka. Ujmując w swoich wierszach cierpienie natury, pokazując dotkliwe skutki jej dewastowania, pragnie udzielać jej głosu albo mówić w jej imieniu.
\end{abstract}




\section{człowiek ekologia}

Tadeusz Śliwiak

\section{NOTA O AUTORCE:}

Katarzyna Niesporek - doktor, adiunkt w Instytucie Literaturoznawstwa Uniwersytetu Śląskiego w Katowicach, sekretarz Komisji Historycznoliterackiej PAN - oddział w Katowicach, czasopisma „Rana. Literatura - Doświadczenie - Tożsamość”, Komitetu Okręgowego Olimpiady Literatury i Języka Polskiego w Katowicach. W kręgu jej zainteresowań badawczych znajduje się krajowa i emigracyjna poezja polska drugiej połowy XX wieku, literatura na Górnym Śląsku oraz twórczość najnowsza. Artykuły naukowe i recenzje ogłaszała w tomach zbiorowych i czasopismach. Autorka monografii „Ja” Świetlickiego (2014); Eda. Szkice o wyobraźni i poezji (2015); Boskie, ludzkie. Studia o poetyckim doświadczaniu Boga (2017), Hałda. O ślaskiej wyobraźni symbolicznej (2019). Współredaktorka tomów zbiorowych. 